\title{
The Effect of Problem Based on Learning Models Using Macromedia Flash and Motivation Against Student Learning Outcomes on Environmental Pollution Materials
}

\author{
Tiara Mahdalena Arwira', Retno Dwi Suyanti², Daulat Saragi ${ }^{2}$ \\ ${ }^{I}$ Postgraduate Basic Education Student, Universitas Negeri Medan, Indonesia \\ ${ }^{2}$ Postgraduate Basic Education Lecturer, Universitas Negeri Medan, Indonesia \\ tiaramahdalenaarwira@gmail.com
}

\begin{abstract}
This study aims to determine: 1) whether the learning outcomes of students taught with problem-based learning models using macromedia flash are better than students taught with direct learning models, 2) whether the learning outcomes of students who have high motivation are better than students who have low motivation,3) is there an interaction between the two learning models with the level of motivation in influencing student learning outcomes. This research is a quasi experimental study. The population in this study were all grade VII students of MTs Lab. UINSU Medan Academic Year 2018/2019 which consists of three classes. Samples were selected by cluster random sampling of two classes. . The instrument used was a student learning motivation questionnaire and student learning outcomes test. Data obtained from the research instrument were then analyzed using two-way anova in the SPSS 14.0 for Windows program. The results showed that: Student learning outcomes taught by the problem-based learning model were better than students taught by the direct learning model (sig. $=0.027<0.05)$, Student learning outcomes that were highly motivated were better than students who were motivated low (sig. $=0,000<0.05$ ), There is an interaction between the two learning models with the level of motivation in influencing student learning outcomes ( sig. $=0.018<0.05$ ).
\end{abstract}

Keywords: Problem based learning model; macromedia flash; motivation; environmental pollution.

\section{Introduction}

Learning outcomes are a description of how students understand the material delivered by the teacher. Learning outcomes are outputs in the form of numbers or letters obtained by students after receiving learning material through a test or exam submitted by the teacher. From these learning outcomes the teacher can receive information on how far students understand the material being studied.

The success of students in achieving learning outcomes in each student is different. The factors that influence student success in achieving learning outcomes are grouped into two namely internal factors and external factors. Internal factors are all factors that originate from within the student, including physiological factors namely the student's body and psychological factors which include the student's intelligence or intelligence, motivation, interests, attitudes, talents. External factors are all factors outside the student's self, including the natural environment and the socio-cultural environment, while the nonsocial or instrumental environment, namely curriculum, programs, learning facilities, teachers (Kompri, 2016: 227). Science learning outcomes are shown by the achievements of students. These achievements are in the form of values obtained when children follow the learning process in class.

Motivation is one of the important factors in supporting students' understanding and success in learning. With the motivation, students can more easily learn and understand the material presented by the teacher because students have the enthusiasm of learning in the 
teaching material delivered by the teacher. If students do not have enthusiasm, students will be reluctant and lazy to learn it.

Learning is a process of interaction between teacher and students and the elements in them. The teacher is the most dominant factor that determines the quality of learning. Good quality of learning will certainly produce good learning outcomes. According to Rusman (2012: 148):

In the learning system the teacher is required to be able to choose the right learning method, be able to choose and use learning facilities, be able to choose and use evaluation tools, be able to manage learning in the classroom or in the laboratory, master the material and understand student characters.

Science learning requires tools (media) to explain abstract science lessons to students. How to deal with abstract explanations by using ICTs in science learning. The advantage of using ICT is as a means of displaying messages in the form of media images, films, sound (Kusuma, 2015: 387).

Media is used in learning so that the delivery of messages to students in accordance with what the teacher wants in achieving learning objectives. The existence of media in learning as a tool to convey abstract messages to the concrete. Media in ICT, especially on computer-aided media, can display audio, visual and audio-visual media. Computer-aided learning media facilitate student learning in learning subject matter delivered by the teacher. One of the ICT media that is able to concretize the message conveyed by the teacher to students is Macromedia flash (Kusuma, 2015: 387).

Macromedia flash is used as a tool for making presentations that have a very high level of theory and illustration. Macromedia flash is capable of displaying abstract teacher explanations by displaying simulations of natural science materials such as cells and networks. The appearance of the simulation is presented in the form of animated moving pictures and videos (Kusuma, 2015: 387).

The purpose of this study are: 1) Determine the effect of the problem-based learning model using Macromedia flash on the learning outcomes of science on environmental pollution material in class VII MTs Lab UIN SU Medan 2018/2019 Academic Year. 2) Determine the effect of learning motivation on learning outcomes of science on environmental pollution materials in class VII MTs Lab UIN SU Medan 2018/2019 Academic Year. 3) Knowing the interaction between problem-based learning models using Macromedia flash and learning motivation towards the learning outcomes of science in environmental pollution material class VII MTs Lab UIN SU Medan 2018/2019 Academic Year.

\section{Review of Literature}

\subsection{Learning Outcomes}

All consequences that can occur and can be used as indicators of the value of using a method under different conditions according to Reigeluth as quoted by Keller are learning outcomes. This effect can be intentionally designed, because it is a desirable result and can also be a real result as a result of using certain teaching methods.

Learning outcomes, according to Bloom, are behavioral changes that include three domains, namely the cognitive, affective and psychomotor domains. The cognitive domain includes learning goals related to recalling knowledge and developing intellectual abilities 
and skills. The affective domain includes learning goals that explain changes in attitudes, interests, values and the development of appreciation and adjustment. The psychomotor domain includes behavioral changes that indicate that students have learned certain physical manipulative skills.

Anderson and Karthwohl (2001: 28-29) call the cognitive domain of Bloom's taxonomy revised into two dimensions, namely the dimensions of cognitive processes and the dimensions of knowledge. The dimensions of cognitive processes consist of six levels: (1) memory, (2) understanding, (3) application, (4) analysis, (5) evaluation and (6) creating. Whereas the dimension of knowledge consists of four levels: (1) factual knowledge, (2) conceptual knowledge, (3) procedural knowledge and (4) metacognitive knowledge.

The revision shows that Anderson and Karthwohl divided their taxonomy into two dimensions (cognitive processes and knowledge) which, according to Bloom, were only one cognitive dimension. In addition, there is a difference in the dimensions of cognitive processes with Bloom, namely the first dimension (prior memory of knowledge), the fifth dimension (previous evaluation of synthesis) and the sixth dimension (creating previous evaluation). Whereas in the dimension of knowledge (previously in the first level of the cognitive area), Anderson and Karthwohl divided it into four levels, namely factual, conceptual, procedural and metacognitive knowledge.

Factual knowledge, according to him, consists of the basic elements used by experts in communicating their scientific disciplines, understanding them and organizing them systematically. The two subtypes of factual knowledge are terminological knowledge and knowledge of specific details. While conceptual knowledge is knowledge of the categories and classifications and the relationship between the two, namely forms of organized and more complex forms of knowledge. The three subtypes of conceptual knowledge are knowledge of classifications and categories, knowledge of the principles of generalization and knowledge of theories, models and structures.

Procedural knowledge is knowledge of how to do something, maybe completing routine exercises to solve problems. The three subtypes of procedural knowledge are knowledge of special skills, algorithms, knowledge of subject-specific methods and techniques, and knowledge of criteria when using appropriate procedures.

Metacognitive knowledge is knowledge about general understanding and awareness of knowledge about one's understanding, for example how to make students more aware and responsible for their own knowledge. The three subtypes of metacognitive knowledge are strategic knowledge, conditional and contextual knowledge and self-knowledge. Examples of self-knowledge, such as knowledge where someone is considered capable in some fields of work, but not capable in other fields of work.

Meanwhile, the new abilities obtained after students learn according to Gagne, Briggs and Wager (1992: 35) are capabilities or performances that can be observed as learning outcomes. He further said, categorizing the five abilities as learning outcomes, namely intellectual skills, cognitive strategies, verbal information, attitudes and motor skills. Intellectual skills, namely in the form of skills that make individuals capable and able to interact with the environment using symbols, such as the ability to distinguish what is shown by an object with other objects (discrimination), the ability to identify objects in an environment by giving a certain name or concrete concept (concret concept), the ability to identify the concept (defined concept), a broader intellectual ability, namely the rules (rules) and the ability of a person to know the things learned and the ability to apply them to solve a 
problem (higher-order rules-problem solving). While Dick and Carey (1996: 35) grouped intellectual skills into the four most common types, namely discrimination, forming concepts, applying rules and problem solving. Cognitive strategies, which refer to the way students show attention, memory and thoughts or abilities that govern the way students manage their learning.

On the other hand, Dick and Carey have eliminated the ability of cognitive strategies for a variety of reasons, including that cognitive strategies are meta processes used to ensure learning is done. Verbal information, namely the ability to obtain labels or names, facts and knowledge fields that are neatly arranged. Attitudes, namely the complex human condition that gives effect to behavior towards society, things, and events. Ability that influences the choice of actions to be taken. Motor skills, which are abilities that underlie the implementation of physical actions in a smooth manner.

From the description above, it can be concluded that learning outcomes are changes in individual behavior which includes the cognitive, affective and psychomotor domains. The behavior change is obtained after students complete their learning program through interactions with various learning resources and learning environments.

\subsection{Problem Based Learning}

Problem-based learning is not designed to help teachers convey large amounts of information to students. This learning is designed especially to help students develop thinking skills, problem solving skills, intellectual skills, learn the roles of adults by experiencing them in various real situations and becoming independent and autonomous students. Arends (2008: 41) states that the problem based learning model is "a learning model with a student learning approach to authentic and meaningful problems to students that serves as a foundation for student investment and inquiry, so students can compile their own knowledge, develop higher skills, independent students and increase self-confidence ". This model is characterized by the use of real life problems as something that enhances critical thinking and problem solving skills, as well as gaining knowledge of important concepts. This learning model prioritizes the learning process where the teacher's task must focus on helping students achieve selfdirected skills. Learning based on the problem of its use in higher levels of thinking, in problem-oriented situations, including how to learn.

Some theories support problem-based learning as an approach to learning, so problembased learning is based on a strong foundation by various experts. Dewey's view of education sees schools as a reflection of a larger society and classes become a laboratory for the investigation and eradication of real life problems in Arends (2008: 46). Problem-based learning borrows Piaget's opinion in 1954 that if students are involved in the process of obtaining information and constructing their own knowledge, learning will become meaningful.

While Vygotsky believes that intellectuals develop when individuals face new and confusing experiences and when they try to overcome the descriptions arising from these experiences in Arends (2008: 47). According to Vygotsky students have two different levels of development, namely: (1) The level of actual development, which determines the current intellectual function of an individual and his ability to learn for himself certain things, (2) The level of potential development that is that can be enabled or achieved by individuals with the help others, such as teachers, parents or even peers who are smarter, more advanced and more developed. 
Bruner argues that in essence the aim of learning is not only to enlarge students' knowledge base, but also to create possibilities for invention and discovery. Bruner considers the very important role of dialogue and social interaction in the learning process. Based on the Bruner concept, a teacher who will use a problem-based approach must emphasize the following points in the learning process: (1) Give strong pressure to build active involvement of all students in each step and the learning process carried out, (2) Encourage students to construct knowledge by students themselves without being dominated by the teacher, (3) The teacher gives questions to students to explore various investigative activities until students arrive at the discovery of ideas and construct them into a theory building, at least to a deep understanding of theory, (4) The orientation used is inductive rather than deductive orientation.

\subsection{Learning Motivation}

Motivation and Learning are two things that influence each other. Students will actively study if he has the motivation to learn. Uno (2011: 11), defines learning as a process of interaction between stimuli (which may be thoughts, feelings or movements) and responses. This understanding is in line with the opinion of Uno (2011: 15), which states that learning is a process or interaction carried out by someone in obtaining something new in the form of behavior change as a result of learning experiences. Changes in behavior are seen in students' mastery of new patterns of response (response) to the environment in the form of skills (skills), knowledge (knowledge), attitude or attitude (attitude), ability (ability), understanding (understanding), emotions ( emotion), appreciation, physical, manners, and social relations.

In the learning process, motivation is needed. According to Hamalik (2013: 161) motivation is very determining the level of success or failure of student learning, learning without motivation would be very difficult to succeed. Because, someone who has no motivation in learning, will not be possible to do learning activities. This is a sign that something that will be done does not touch his needs. Everything that attracts the interests of others may not necessarily attract other interests as long as something is not in contact with their needs (Djamarah, 2011).

Learning motivation is a psychiatric aspect that is developing, meaning that it is influenced by the student's psychological condition and psychological maturity. Dimyati and Mudjiyono (2010: 97-99), suggested several elements that influence motivation in learning, namely:

- Student ideals and aspirations. The ideals will strengthen students' learning motivation both intrinsic and extrinsic. Because the achievement of an ideal will realize selfactualization.

- Student Ability. The desire of a child needs to be accompanied by the ability or ability to achieve it. The ability to strengthen children's motivation to carry out development tasks.

- Student Conditions. Student conditions that include physical and spiritual conditions affect learning motivation, A student who is sick, will interfere with the attention of learning, by contrast a healthy student, will easily focus attention in learning.

- Student Environmental Conditions. Student environment can be in the form of natural conditions, neighborhoods, peer relationships, and social life. The condition of a 
healthy school environment, a safe, peaceful, orderly, and beautiful environment will increase the spirit of learning motivation that is stronger for students.

\section{Research Methods}

This type of research is a quasi experiment. The population in this study were all eighth grade students of MTs Lab UIN SU Medan, 2018/2019 Academic Year, totaling 90 students who were distributed in 3 classes and had the same characteristics. From 3 (three) classes, the study sample was taken 2 (two) classes. Sampling was done by cluster random sampling. One class was taken as an experimental class taught with a problem based learning model with Macromedia flash, and another class as a control class taught with a direct learning model. The instrument used in this study was a matter of learning achievement tests and student motivation questionnaires. Data obtained from the research instrument were then analyzed using two-way ANOVA in SPSS 14.

\section{Results and Discussion}

The test results were carried out by two-way ANOVA with the General Linear Model (GLM) Univariate SPSS 14, which can be seen in Table 1.

Table 1. Results of Two-Way Anava Test

\begin{tabular}{|c|c|c|c|c|c|}
\hline Component & $\begin{array}{l}\text { Total } \\
\text { square }\end{array}$ & df & $\begin{array}{r}\text { Avera } \\
\text { ge Squared }\end{array}$ & $\mathbf{F}_{\text {count }}$ & Sig. \\
\hline Model & 0,025 & 1 & 0,025 & 5,179 & 0,027 \\
\hline Motivation & 0,484 & 1 & 0,484 & 99,60 & 0,000 \\
\hline $\begin{array}{l}\text { Model * } \\
\text { Motivation }\end{array}$ & 0,029 & 1 & 0,029 & 5,941 & 0,018 \\
\hline
\end{tabular}

From the anava test results in Table 1, it is used to answer the hypotheses raised in this study. The following is a description of the results of the hypothesis test.

\subsection{The Effect of Problem Based Learning Models Using Macromedia Flash on Science Learning Outcomes}

Based on research conducted that students who are taught by using problem-based learning models using macromedia flash obtain an average value of science learning outcomes is greater than the results of learning science with direct learning models. From the hypothesis testing that has been done, it can be concluded that there is a significant influence of learning outcomes between students who are taught using the problem-based learning model with Macromedia flash and students who are taught using direct learning models. Based on the two line Anava test results obtained significance value of the learning model of 0.027 , because the value of sig. $0.027<0.05$ so the results of hypothesis testing reject Ho and accept $\mathrm{Ha}$ alpha level of $5 \%$ meaning that the learning outcomes of students who are taught with problem-based learning models using macromedia flash are greater than the learning outcomes of students who are taught with direct learning models. The results of this study are 
supported by several previous studies which stated that the problem based learning model was significantly more effective than direct learning such as Permana and Harduyo., 2015: 1067-1073: Okmarisa, Darmana and Suyanti., 2016: 130-135: Nafiah and Suyanto., 2014: $125-143$.

In the implementation of the learning problem-based learning model combined with using macromedia flash media. The application of problem-based learning models with Macromedia Flash makes it easier for researchers to convey information to students so that the learning process in the classroom becomes innovative and not boring for students. Unlike the case with direct learning that puts practice on students. Knowledge is taught by training students, the tendency of students to memorize the knowledge given by the teacher. A series of activities are carried out instructionally without giving the opportunity for students to find their own knowledge. This series of instructional activities conditions the silent classroom situation without student activity, paying attention only to the teacher's explanation. In this direct learning students also lack communication with their peers in the learning process in class. The passive activity has an impact on the weak absorption of student knowledge and student learning outcomes also become low.

\subsection{Effect of Learning Motivation on Science Learning Outcomes}

Based on the results of research conducted shows that there is an influence of learning outcomes between groups of students who have high motivation with groups of students who have low motivation, where students who have high motivation to learn better than students who have low motivation to learn. Based on the two-way Anova test conducted, the results of the analysis of variance analysis obtained a significance value of motivation of 0,000 , because the value of sig. $0,000<0.05$ so that the results of hypothesis testing reject Ho and accept Ha with an alpha level of 5\% meaning that it means that there is an influence between high motivation and low motivation on the learning outcomes of Natural Science. This is consistent with previous research conducted by Hanim, Suyanti and Harahap (2018 : 107115) states the effect of high motivation levels on learning outcomes of Science is better than low motivation levels.

\subsection{The interaction between problem-based learning models using Macromedia flash and learning motivation towards science learning outcomes}

Based on the results of research conducted shows that there is an interaction between learning models with motivation in influencing student learning outcomes. Based on the twoway Anova test, the results of the analysis of variance analysis showed that the significance value of the learning model * motivation was 0.018 , because the sig value $0.018<0.05$ so the results of hypothesis testing reject Ho and accept Ha with an alpha level of 5\%, meaning that there is an interaction between problem-based learning models using macromedia flash and motivation in improving student learning outcomes.

\section{Conclusions}

Based on the results of research and discussion, the conclusion is that student learning outcomes taught with problem-based learning models are better than students taught with direct learning models (sig. $0.027<0.05$ ), student learning outcomes that have high motivation are better than students who have low motivation (sig. $0,000<0.05$ ) and there is 
an interaction between the two learning models with the level of motivation in influencing student learning outcomes (sig. $0.018<0.05$ ).

\section{References}

Anderson, R. W. \& Karthwohl D. R. (2001). A Taksonomi for Learning, Teaching, and Assessing: A Revision of Bloom's Taksonomi of Eductional Objectives. New York : Addison Wesley Longman, Inc.

Arends, R. (2008). Learning to Teach ( $7^{\text {th }}$ ed.) Belajar untuk Mengajar (Terjemahan Helly Prajitno Soetjipto dan Sri Mulyantini Soetjipto pada Tahun 2008). Yogyakarta: Pustaka Pelajar.

Dick, Walter, Carey, L., \& Carey, J. O. (1996). The systematic Design of Instruction sevent edition. 'Upper Saddle River, New Jersey: Pearson Education.

Dimyati \& Mudjiono. (2010). Belajar dan Pembelajaran. Jakarta : Rineka Cipta.

Djamarah. (2011).Psikologi Belajar. Jakarta : Rineka Cipta.

Gagne, R. M., Briggs, L. J., \& Wager, W. W. (1992). Principles of instructional design $4^{\text {th }}$ ed. Orlando: Holt, Rinehart, and Winston.

Hamalik, O. (2013). Proses Belajar Mengajar. Jakarta : Bumi Aksara.

Hanim, F., Suyanti, R. D., \& Harahap, F. (2018). Pengaruh Lembar Kerja Peserta Didik Berbasis Keterampilan Proses Sains dan Motivasi Terhadap Hasil Belaar IPA Kelas IV SD Negeri 164330 Tebingtinggi. Jurnal Tematik. 7 (1) 107 - 115, Juni 2018.

Kompri. (2016). Motivasi Pembalajaran Perspektif Guru dan Siswa. Bandung: PT Remaja Rosdakarya.

Kusuma, P.S., Chamisijatin, L., \& Widodo, N. (2015). Pengaruh Macromedia Flash Terhadap Hasil Belajar Siswa Kelas X IPA SMA Negeri 4 Pasururan. Prosiding Seminar Nasional Pendidikan Biologi 2015, yang diselengagarakan oleh Prodi Pendidikan Biologi FKIP Universitas Muhammadiyah Malang, tema: "Peran Biologi dan Pendidikan Biologi dalam Menyiapkan Generasi Unggu dan Berdaya Saing Global", Malang, 21 Maret 2015.

Nafiah, Y. N., \& Suyanto, W. (2014). Penerapan Model Problem Based Learning untuk Meningkatkan Keterampilan Berpikir Kritis dan Hasil Belajar Siswa. Jurnal Pendidikan Vokasi. 4 (1) 125 - 143, Februari 2014.

Okmarisa, H., Darmana, A., \& Suyanti, R. D. (2016). Implementasi Bhana Ajar Kimia Terintegrasi Nilai Spiritual dengan Model Pembelajaran Problem Based Learning (PBL) Berorientasi Kolaboratif untuk Meningkatkan Hasil Belajar Siswa. Jurnal Pendidikan Kimia. 8 (2) 130 - 135, Agustus 2016.

Permana, G., \& Haryudo, S. I. (2015). Pengembangan Model Pembelajaran Berbasis Masalah Menggunakan Software Macromedia Flash pada Mata Peljaaran Instalasi Penerangan Listrik untuk Meningkatkan Hasil Beljaar Peserta Didik di Kelas XI TIPTL SMK Negeri 1 Nganjuk. Jurnal Pendidikan Teknik Elektro. 4 (3) 1067 - 1073, Tahun 2015.

Rusman. (2012). Model-Model Pembelajaran Mengembangkan Profesionalis Guru. Jakarta: Raja Grafindo Persada.

Uno, H. B. (2011). Teori Motivasi dan Pengukurannya. Jakarta : Bumi Aksara. 